\title{
An Investigation into Motivational Self-Systems of Turkish English Language Learners in Higher Education
}

\author{
Zeynep CEYHAN-BINGÖL* \\ School of Foreign Languages, Adana Alparslan Türkeş Science and Technology University \\ Balcalı Mh., Çatalan Cd., No:201/2 01250 Sarıçam/Adana, Turkey \\ Kenan AKARSLAN \\ School of Foreign Languages, Adana Alparslan Türkeş Science and Technology University \\ Balcalı Mh., Çatalan Cd., No:201/2 01250 Sarıçam/Adana, Turkey \\ Prof. Dr. Yonca ÖZKAN \\ English Language Teaching Department, Çukurova University, Adana, Turkey
}

\begin{abstract}
Motivational self-systems have been researched in various educational settings including the English language teaching environment. However, motivational self-systems in the Turkish educational context still need to be investigated more due to the scarcity of studies in the local context, specifically with relation to the majors of the language learners. The current mixed-methods sequential explanatory study focuses on Turkish language learners' motivational self-systems and their correlation with the major of the learners. The quantitative data were collected from 118 participants in the Fall Term of 2019-2020 Academic Year based on convenience sampling at a language preparatory school of one of the state universities in Adana, Turkey through an adapted questionnaire. The qualitative data were gathered from 40 participants through reflective papers the participants were asked to keep at the beginning and end of the semester. The quantitative data were analyzed via SPSS 21 and the qualitative data were analyzed through thematic analysis. The findings indicated that there was no dominant L2MSS of Turkish language learners. The findings implied that the ideal L2 self of Turkish learners did not strongly correlate with their majors while their ought-to L2 self-had a strong correlation for some of the majors.
\end{abstract}

Keywords: ELT, L2 motivational self-systems, ideal L2 self, ought-to L2 self, Turkish language learners.

DOI: $10.7176 / \mathrm{JEP} / 11-34-02$

Publication date: December $31^{\text {st }} 2020$

\section{Introduction}

Learning English has become a vital part of life and its reflection is observed in language education all around the world, also it has been integrated into school curricula in various contexts. Several factors are affecting the process of English learning such as culture, economy, history, or education system of any country in general (Sawir 2005; Walqui 2000). Specifically, individual differences play a crucial role throughout the English learning process (Skehan 1991). Individual differences can include age, gender, proficiency, department/ major, positive and negative emotions, use of language learning strategies, and motivation of learners (Ehrman, et al. 2003).

The studies about motivation and L2 have more than 50 years of history and there have been various developments in the field (Dörnyei and Chan 2013). One of the changes related to motivation and L2 is Dörnyei's L2 Motivational Self System (L2MSS) which is based on language learners' perceptions of themselves, especially about their future self (Dörnyei 2005, and Dörnyei 2009). Based on the system, three sources of motivation to learn L2 are intrinsic desires of a language learner to use L2 effectively, a language learner's social environment, and a language learner's experiences during the L2 learning process (Dörnyei and Chan 2013).

There have been various studies focusing on the L2MSS of language learners in different contexts including China, Japan, and Iran by numerous scholars (Martinović 2018; You et al. 2016). Additionally, there have been different studies in the Turkish educational context focusing on the issue (Bursal1, and Öz 2017; Öztürk and Gürbüz 2013; Şakiroğlu and Dikilitaş 2010). Despite the various studies on the issue, the current study more comprehensively examines the relationship between the two types of self and a different parameter.

\section{Literature Review}

Motivation research has been conducted for a long time in ELT, and it has both changed and developed thanks to some crucial studies (Dörnyei 1994; Gardner 1985; Gardner and Lambert 1972; Gardner and McIntyre 1992). Research about language learning and motivation dates back to Gardner and Lambert (1972) who revealed the significance of culture and attitude during the language learning process and focused on integration. Through its wide use until the 1990s, it could not correspond to different situations in which there was no integration or certain L2 community identity (Dörnyei et al. 2006). It is also accentuated that there is no specific community in the world due to globalization and integration concepts taper off (Dörnyei 2009). 
Williams and Burden (1997) define motivation as one of the effective factors in learning since it is likely for language learners to learn if they have a desire. Dörnyei (1998) highlights that motivation is the fundamental force to start L2 learning, and it also enables the learning process to be continuous.

One of the milestones related to motivation in education is L2MSS (Dörnyei 2005, Dörnyei 2009) which deals with the perception of language learners about themselves. Dörnyei attributes his framework to "the possible selves theory" of Markus and Nurius (1986) and the "self-discrepancy theory" of Higgins (1987). L2MSS focuses on three main sources of the L2 learning process, which are a learner's intrinsic desires, social pressure from the social environment, and the real experience during the L2 learning process (Dörnyei and Chan 2013). The main elements constituting L2MSS are ideal L2 self, ought-to L2 self, and L2 learning experience (Dörnyei, 2005).

According to Dörnyei (2009), the ideal L2 self is related to a specific facet of the L2 ideal, so it is essential to reduce the possible discrepancy between the real and ideal self. Ryan and Dörnyei (2013) reveal that the ideal L2 self of language learners may penetrate the motivation of the learners and their proficiency level in the target language. Additionally, Dörnyei (2014) delineates that if a language learner has an inadequate level of ideal L2 self, that person may not possess high motivation in the L2 learning process. Ought-to L2 self is concerned with the features that language learners believe they need to avoid potential negative results (Dörnyei 2009), which might be interpreted as the social pressure from the social environment. Dörnyei and Chan (2013) explain that duties, obligations, and expectations are related to ought-to L2 self. The L2 learning experience is about situationally specific motives based on the experience and environment. Such experiences can be related to various factors like success or failure, the teacher, and the language learning environment (Dörnyei and Ryan 2015).

Various studies utilizing L2MSS have been conducted since its emanation. The longitudinal study conducted with 169 participants in Sweden by Henry (2009) elicits that ideal L2 self increases significantly in teenage girls despite its decrease in teenage boys for four years. In the Iranian context including 1011 Iranian high school students, Papi (2010) finds out that ideal L2 self and L2 learning experience decrease the English anxiety of students whereas ought-to L2 self leads them to feel more anxious. You, Dörnyei, and Csizé (2016) investigate a great number of Chinese secondary school and university students and conclude that imagery and vision are significant to construct L2 motivation. Additionally, Martinović (2018) examines the English language learning motivation of 543 Croatian university students based on L2MSS and learner differences. Her study reveals that the length of studying does not affect motivation significantly while grade levels and gender do.

The studies related to L2 and motivation have shined out in Turkey recently. Sakiroğlu and Dikilitaş (2012) focus on the language learning motivation of 129 tertiary level Turkish language learners and they find out that female participants have a higher level of motivation, and motivation level of the participants is higher when their achievement increases, and proficiency level and motivation of the participants are interrelated. In another study conducted with 383 pre-intermediate students in Turkey, anxiety, and gender are addressed and the findings reveal female language learners are more motivated for English learning although they are more anxious in English speaking activities in classes. (Öztürk and Gürbüz 2013). Bursalı and Öz (2017) investigate the relationship between willingness to communicate and ideal L2 self with the participation of 56 university students and they find a positive and highly significant relationship between two constructs.

In the current study, the major of Turkish L2 learners have been examined within the scope of Dörnyei's L2MSS (Dörnyei 2005, Dörnyei 2009). The present study explores Turkish language learners' ideal L2 self and ought-to L2 self. Additionally, the research focuses on the correlation between L2MSS and the participants' majors. Targeting to fill out the gaps aforementioned, the study tries to shed light on the dominant L2 motivational systems employed by Turkish language learners at a language preparatory school, and the correlation between the participants' motivational self-systems concerning their major. Taken together, the study seeks answers to the following research questions:

Q1: What are the dominant L2 motivational self-systems of Turkish language learners at a language preparatory school?

Q2: Is there any correlation between Turkish language learners' L2 motivational self-systems regarding their majors?

Q3: How do the majors of Turkish language learners correlate learners' motivational self-systems?

\section{Method}

\subsection{Participants}

The participants in the quantitative part of the study were native speakers of Turkish including 76 males, 41 females, and one other gender, aged between 18 and 25. They were all students at the preparatory year of a state university in Adana, Turkey in the Fall Term of Academic Year of 2019-2020. Their departments include 'Aerospace Engineering', 'Bioengineering', 'Business Administration', 'Civil Engineering', 'Computer Engineering', 'ElectricalElectronic Engineering', 'Energy Systems Engineering', 'Industrial Engineering', 'International Relations', 'International Trade and Finance', 'Management Information Systems', 'Mechanical Engineering', 'Political Science and Public Administration' and 'Translation and Interpreting'. The students are placed into different classes based 
on their English level through a proficiency and a placement test prepared and implemented by the institution every year. While choosing the participants for the quantitative phase of the study, the convenience sampling method was utilized since the participants were chosen based on their availability, convenience, and volunteerism (Creswell 2012).

The participants in the qualitative phase of the study were 40 of the students, including 22 males and 17 females, who had already taken part in the study by filling the questionnaire. To choose the participants for this phase, convenience sampling was used as the participants were the easiest to available and they were all volunteers to participate in the study (Creswell 2012).

\subsection{Instruments}

The quantitative data were collected from 118 participants through a five-point Likert scale questionnaire adapted from the motivation questionnaire by Taguchi, Magid, and Papi (2009). The questionnaire was translated into Turkish by the researchers besides the advice of colleagues who had expertise in the field. The translation procedure involved the 'back translation' method to consolidate the reliability and the validity of the adaptation. According to Tyupa (2011), back-translation is a process in which the translated text is re-translated back into the source language by a translator who has not seen the original version of the text. Therefore, the discrepancies between the back-translation and the original text are taken into consideration to see whether there are any major translation errors in the target language version (Tyupa 2011).

As the main focus of the research is the ideal L2 self and ought-to L2 self of the participants, some parts which focused on instrumentality or attitudes towards learning English were omitted. Also, some alterations were made in the original ideal L2 self and ought-to L2 self-statements because direct translations would cause a loss or overload of meaning. 'I can imagine...' statements were translated as '...hayal edebilirim' instead of '...hayal edebiliyorum' as the latter was thought by the researchers to suggest that the participant is supposed to be imagining the item at the moment of responding to the questionnaire whereas the former suggests that the imagination covers both present and future. In other words, participants are expected to be considering both their present and future self-vision about the statements provided.

The ought-to L2 self-items were asked in a separate part where the items focus on how the participants perceive the approach of the individuals, groups, or the society around them. Some cultural elements were altered to render learners' familiarity with the content of items. For instance, two national standardized examinations, YDS (Yabanc1 Dil Sinav1 - Foreign Language Exam) and YÖK-DİL (Council of Higher Education Language Examination) were integrated into the items to see the possible imposition of external factors in the local context.

In addition to the quantitative data collection tool, the researchers devised a reflective paper format to obtain qualitative data. The participants were expected to fill in the reflective papers at the beginning and the end of the semester. There are two open-ended incentives in Turkish in the reflective papers:

1. My general thoughts on English (If there is, what I have experienced and my emotions)

2. $\quad$ My experience this semester (If there is what I lived through and my emotions)

The questions aim to explore the general approach of the participants towards learning English. The researchers expected to analyze and interpret the participants' wider ideal L2 self or ought-to L2 self-motivational clues through the qualitative data.

\subsection{Procedure}

\subsubsection{Pilot study}

Before administering the questionnaire, the researchers conducted a pilot study to notice, eliminate, or revise any potential flaws in the items on the questionnaire. Twenty-seven participants studying in a Moving (M) level class of the preparatory year participated in the pilot study based on convenience sampling. According to the institutional policy, the $\mathrm{M}$ level is defined as corresponding to elementary level and A1 in CEFR terms. The data of the piloting were analyzed and the Cronbach Alpha score of the questionnaire was reported as 0,881 . To resolve ambiguity problems, the participants were asked if there existed any statements in the questionnaire they could not understand. Although there were not any serious problems with the questionnaire, the feedback obtained from the participants helped the researchers to revise the questionnaire content.

3.3.2. Data collection process

The questionnaire was administered to the participants in October and November 2019 since it was not possible to manage the proper time with all classes in a month. The participants in each class were informed by one of the researchers about the aim of the study. They were also assured that participation was based on voluntarism and they were free not to participate in the study. Additionally, it was mentioned that there were no right or wrong answers so their sincere answers were crucial for the study to be more valid and reliable.

The participants were asked to fill in a reflective paper format twice during the fall term to collect qualitative data. The reflective paper formats were distributed to the participants each time by one of the researchers/first and second authors. Each session in creating papers lasted $\sim 15 \mathrm{~min}$. The participants individually responded to the 
papers in their mother tongue to overcome language-related constraints as well as to maintain a low affective filter. It was also mentioned that their participation was based on their voluntarism and they could choose not to participate in the study. Moreover, it was stated there were no right or wrong answers, so their sincere answers were significant for the study.

3.3.3. Data analysis

SPSS 21 was utilized to analyze the quantitative data of the study. All the data inputted into the program, and both Linear Regression Analysis and ANOVA were used to find out the correlation between the major of the participants and their L2MSS. The rationale to choose linear regression analysis was that it enables to describe of the relationship between a dependent and independent variable. While analyzing the qualitative data obtained through the reflective papers, thematic analysis was used. Thematic analysis was conducted according to the six steps by Braun and Clarke (2006). First, the researchers familiarized themselves with the data and they formed the initial codes for the themes. Then, they started to turn codes into themes and the themes were reviewed. Lastly, the researchers named the themes and produced the findings of the data. Member checking and colleague support were utilized during the analysis process to avoid possible bias.

\section{Findings and discussion}

\subsection{Dominant L2MSS of Turkish language learners}

When the L2MSS of Turkish language learners at a language preparatory school was examined, it was found out that there was no dominant L2MSS. While the mean of significance obtained from the ideal L2 self category was 0.46 , the mean of significance obtained from the ought-to L2 self-category was 0,449 , which indicated there was not any significant difference among major of the participants and their dominant L2MSS in the study. The findings of the current study corresponded to Ditual's study (2012) in which Philippine language learners were motivated to learn English both externally and internally. It could be interpreted that Turkish language learners have both internal and external motivation to learn English.

4.1.1. Ideal L2 self of Turkish language learners

When the ideal L2 self of Turkish language learners was examined, the findings suggested that almost all of the participants could imagine themselves watching movies and TV series in English. In her study, Özçalışan (2012) found out that English movies and songs were one of the main factors increasing the motivation of English learners in her study. Additionally, in the study, a great number of the participants $(95.7 \%)$ could imagine themselves living abroad (See Table 1). The findings were parallel with the findings of Bursalı and Öz's study (2017) that revealed that the great majority of the participants tended to imagine themselves living abroad. However, some of the participants $(n=12)$ mentioned they could not imagine themselves having discussions in English, which was different from the findings of Bursalı and Öz (2017) displaying that a good number of the participants could imagine themselves having discussions in English. It may be interpreted that Turkish language learners would like to use English for their daily life in the future, which is related to their ideal L2 self.

[Please insert Table 1. here]

The findings of the qualitative data obtained in October 2019 presented that the participants had different perspectives about learning English (See Figure 1). According to the reflective papers of the participants, 11 codes emerged based on the theme of ideal L2 self. The most common perspective about learning English was to be able to communicate with foreign people. One of the participants explained "Learning English is a nice feeling. I had a short talk with a native English teacher and felt more self-confident" (P-17). Another participant also mentioned, "I can speak English with my foreign friends at the dorm, they are teaching me English" (P-32). The findings were in line with Ditual (2012) who concluded that the participants in the study had their own individual goals and aims to become motivated to learn English. It could be interpreted that Turkish language learners have their reasons and purposes to learn English, and feel motivated to learn English.

[Please insert Figure 1. here]

The second set of qualitative data presented that the participants had various views about learning English (See Figure 2). The reflective papers of the participants revealed 10 different codes about the theme of the ideal L2 self. The most common view based on learning English was to be able to communicate with people from different cultures and countries. One of the participants stated, "It is necessary to learn English because it is a world language" (P-6). Another participant also reflected "I want to go abroad and communicate with people there" (P-22). The findings were consistent with the ones of Öztürk and Gürbüz (2013) who found out that Turkish tertiary level students preferred to learn English to communicate with foreign people and travel to different countries. It could be interpreted that Turkish language learners have various reasons to learn English, uppermost to communicate with people, based on their ideal L2 self.

[Please insert Figure 2. here]

\subsubsection{Ought-to L2 self of Turkish language learners}

Ought-to L2 self of the participants was examined in the study and the findings revealed that most of the participants $(92.4 \%)$ believed studying abroad was one of the basic conditions of their career advancement (See 
Table 2). Martinović (2018) also discovered that both males and females emphasize English for their future careers. Additionally, a great majority of the participants in the present study $(92.3 \%)$ agreed that English was one of the prerequisites for communicating with people from different cultures. However, more than half of the participants $(56 \%)$ in the study disagreed that they were learning English due to the feeling of closeness towards their peers. Unlike the findings of the present study, Dörnyei and Chan (2013) found out that the level of motivation to learn English due to friends was one of the ought-to L2 self factors. It might be concluded that Turkish language learners are motivated to learn English with some external factors including future career aims and communication with people from different cultures.

[Please insert Table 2. here]

The first set of qualitative data presented that the participants had divergent external motivation about learning English (See Figure 3). Five codes related to the theme of ought-to L2 self emerged during the analysis of reflective papers. The most common external motivational factors were learning English due to the majors, job, and life coping strategies in the future. One of the participants verbalized "My department is in English and I want an international future, so I want to speak English fluently" (P-2). Another participant stated "Learning English is important for engineering students. I think English speaking people in our country can succeed more easily in their profession. Also, most of the important articles are in English and it is important to read and comprehend them in English" (P-7). Öztürk and Gürbüz (2013) also revealed in their study that Turkish tertiary level students expressed their enthusiasm about learning English to attain a better job in the future, use English in their departments, and be advantageous in job interviews. It is likely to say that Turkish language learners have their external motivational factors to learn English based on their educational and professional aims.

[Please insert Figure 3. here]

The second set of qualitative data indicated that the participants referred to various external motivational factors about learning English (See Figure 4). Four codes emerged under the theme of ought-to L2 self through the analysis of the reflective papers. The most frequently expressed external motivational factor was the necessity of English in one's life. One of the participants expressed "Learning English contributes to our lives" (P-15). Another participant also verbalized "I think English is a very important language because I need a job, so I must learn English" (P-19). It can be interpreted that Turkish language learners tend to learn English as a means to use the language in different parts of their lives.

[Please insert Figure 4. here]

\subsection{Correlation between L2MSS and Turkish language learners' major}

The correlation between Turkish language learners' L2MSS and their major was also the focus of the current study. The findings revealed that the overall correlation level obtained for the ideal L2 self-category was not significant except for one variable* (See Table 3). Additionally, the findings ascertained that the overall correlation level obtained for ought-to L2 self category was not significant based on the inferential statistical analysis (See Table 4).

[Please insert Table 3. here]

When the ideal L2 self-category and the participants' major was examined, it was found out that the only significant correlation was at 0.018 level, which showed the regression model was significant (See Table 3). All the majors in the study focused on the statement "I can imagine myself reading magazines, newspapers, and books published in English". However, some statements including living abroad and communicating with local people, and communicating in English have a higher significance value than other statements. It might be interpreted that all Turkish language learners aim at reading written and published documents in English no matter which major they have registered.

[Please insert Table 3. here]

When the ought-to L2 self-category and the participants' major was examined, it was deduced that there was no significant correlation between ought-to L2 self and the major of the participants (See Table 4). Nevertheless, the statement "Learning English is important to me because the people I care about think I should learn this language" was more significant than other statements based on the findings of the study. Additionally, one of the participants expressed "I need to learn English for my job in the future" (P-1). It could be glossed that Turkish language learners have the basic extrinsic motivation to learn English.

\subsection{Turkish Language Learners' L2MSS and their majors}

The major of the participants and their L2MSS were examined through the statements of the questionnaire in the study. First, the statements related to the ideal L2 self were analyzed. The findings revealed that 'Management Information Systems' students could imagine themselves having discussions in English $(\mathrm{M}=2.41)$ more than other majors. Although 'Energy Systems Engineering' students were more motivated to imagine themselves living abroad $(M=2.00)$, 'Aerospace Engineering' students were able to imagine themselves as a fluent speaker of English more than others $(\mathrm{M}=2.27)$. 'International Relations' students could imagine themselves writing letters/emails in 
English accurately $(\mathrm{M}=2.28)$, yet 'Civil Engineering' and 'Business Administration' students aimed at using English in different ways with the same rate $(M=2,16)$. The students from 'Management Information Systems' could imagine themselves speaking English like a native speaker $(\mathrm{M}=3.00)$. While 'Electrical and Electronic Engineering' students were eager to use English actively in their career in the future $(M=2.25)$, 'Energy Systems Engineering' students aimed to speak English with different people in their professional and personal lives $(\mathrm{M}=2.00)$. When their ideas about living abroad and communicating with local people via English were considered, three majors ('Political Science and Public Administration', 'Civil Engineering' and 'Energy Systems Engineering') distinguished from other majors at the same rate $(\mathrm{M}=2.00)$. 'Civil Engineering' and 'Energy Systems Engineering' students could imagine themselves speaking English with people from various nationalities $(\mathrm{M}=2.00)$ and students of three different engineering programs ('Electrical and Electronic', 'Civil' and 'Energy Systems') were able to imagine themselves communicating in English more when compared to others $(\mathrm{M}=2.00)$. 'Energy Systems Engineering' students believed in the necessity to use English more $(\mathrm{M}=2.00)$ as well as their desire to travel around different countries $(\mathrm{M}=3.00)$. Though 'Industrial Engineering' students could imagine themselves reading written materials in English $(\mathrm{M}=2.16)$, 'Energy Systems Engineering' students focused on watching movies and TV series in English (M=2.00) more. 'Civil Engineering' students could imagine themselves both as a part of the English education program $(\mathrm{M}=2.33)$ and using English to communicate with people from different cultures $(\mathrm{M}=2.16)$. Additionally, 'Civil Engineering' students were able to imagine themselves speaking English in their social lives $(\mathrm{M}=2.33)$ and giving an English speech successfully to the public $(\mathrm{M}=2.66)$.

When all the findings related to the major of the participants and their ideal L2 self were evaluated, no significant correlation between the major and ideal L2 self of the participants was observed. However, it might be interpreted that 'Civil Engineering' students have more internal motivation to learn English than other majors in the study. Additionally, it might be striking that 'Translation and Interpreting' had lower internal motivation than some of the other majors although it is directly related to the English language itself. Vaezi (2008) also underlines that Iranian university students from 'Electrical and Computer Engineering', and 'Humanities and Social Sciences' departments have a strong internal motivation to learn English to meet and speak with different people, and to be exposed to other nationalities and their cultures.

The statements related to ought-to L2 self and the major of the participants were also examined. It was found out that 'International Relations' students valued English due to the views of the individuals they respected $(\mathrm{M}=2.71)$. However, 'Translation and Interpreting' students believed the importance of English to gain the appreciation of family members $(M=3.70)$. 'Energy Systems Engineering' students aimed at learning English to attain respect and value from their community $(M=4.00)$, their peers $(M=4.00)$, and their teachers $(M=4.00)$. Although 'Translation and Interpreting' students felt urged to learn English due to the anxiety of failure in their English courses $(M=3.60)$, they did not want to cause their families to feel disappointed $(M=4.40)$. Additionally, they were learning English due to the incentives from their close peers $(M=4.40)$. 'Energy Systems Engineering' students tended to learn English as the people they come across believed in the necessity of learning English to be well educated $(\mathrm{M}=4.00)$, yet 'Civil Engineering' students considered English as one of the prerequisites for communicating with people from different cultures $(\mathrm{M}=2.16)$. While 'Energy Systems Engineering' students believed studying abroad was one of the basic conditions for their career advancement $(\mathrm{M}=2.00)$, 'Translation and Interpreting' students became motivated to learn English to receive higher scores from the standardized English examinations $(M=3.10)$.

All the findings related to the major of the participants and their ought-to L2 self were analyzed, it might be interpreted that there was some significant correlation between the major and ought-to L2 self of Turkish language learners. In addition to that, it is likely to conclude that 'Translation and Interpreting' students have a higher external motivation to learn English when compared to other majors in the study. It could be surprising that students from an English-language-related major (Translation and Interpreting) have external motivation to learn English. In this vein, Vaezi (2008) highlights that Iranian tertiary level students were instrumentally motivated to learn English, specifically to use English during their future careers.

\section{Conclusion}

\section{References}

Braun, V. \& Clarke, V. (2006). Using thematic analysis in psychology. Qualitative Research in Psychology, 3(2), $77-101$

Bursalı, N. \& Öz, H. (2017). The relationship between ideal L2 self and willingness to communicate inside the classroom. International Journal of Higher Education, 6(4), 229-239.

Creswell, J. W. (2012). Educational research: Planning, conducting and evaluating quantitative and qualitative research. Boston: Pearson.

Ditual, R. C. (2012). The motivation for and attitude towards learning English. In Paul Robertson \& Roger Charlers Nunn (Eds.), The Asian EFL Journal Professional Teaching Articles - CEBU Conference Issue, 4-21. 
Australia: Asian EFL Journal Press.

Dörnyei, Z. (1994). Motivation and motivating in the foreign language classroom. Modern Language Journal, $78(3), 273-284$.

Dörnyei, Z. (1998). Motivation in second and foreign language learning. Language Teaching, 31(3), 117-135.

Dörnyei, Z. (2005). The psychology of the language learner: Individual differences in second language acquisition. Mahwah, NJ: Erlbaum.

Dörnyei, Z. (2009). The L2 motivational self system. In Zoltán Dörnyei \& Ema Ushioda (Eds.), Motivation, language identity and the L2 self (pp. 9-42). Bristol: Multilingual Matters.

Dörnyei, Z. (2014). Motivation in second language learning. In Marianne Celce-Murcia, Donna M. Brinton, \& Marguerite Ann Snow (Eds.), Teaching English as a second or foreign language (pp. 518-531). Boston: National Geographic Learning/Cengage Learning.

Dörnyei, Z. \& Chan, L. (2013). Motivation and vision: An analysis of future L2 self-images, sensory styles, and imagery capacity across two target languages. Language Learning, 63(3), 437-462.

Dörnyei, Z., Csizér, K. \& Németh, N. (2006). Motivation, language attitudes, and globalization: A Hungarian perspective. Clevedon: Multilingual Matters.

Dörnyei, Z. \& Ryan, S. (2015). The psychology of the language learner revisited. London: Routledge.

Ehrman, M. E., Leaver, B. L., \& Oxford, R. L. (2003). A brief overview of individual differences in second language learning. System, 31(3), 313-330.

Gardner, R. C. (1985). Social psychology and second language learning: The role of attitudes and motivation. London: Edward Arnold.

Gardner, R. C. \& Lambert, W. (1972). Attitudes and motivation in second language learning. Rowley, MA: Newbury House.

Gardner, R. C. \& MacIntyre, P. D. (1992). A student's contributions to second language learning, part I: Cognitive variables. Language Teaching, 25(4), 211-220.

Henry, A. (2009). Gender differences in compulsory school pupils' L2 self-concepts: A longitudinal study. System, 37(2), 177-193.

Higgins, E. T. (1989). Self-discrepancy theory: What patterns of self-beliefs cause people to suffer. Advances in experimental social psychology, 22, 93-136.

Markus, H. R. \& Nurius, P. (1986). Possible selves. American Psychologist, 41(9), 954-969.

Martinović, A. (2018). The L2 motivational self system: Differences among learners Jezikoslovlje, 19(1), 133-157.

Özçalışan, H. (2012). The English learning motivation of higher education students. (Unpublished master's thesis). Afyon Kocatepe University, Afyon.

Öztürk, G. \& Gürbüz, N. (2013). The impact of gender on foreign language speaking anxiety and motivation. Procedia-Social and Behavioral Sciences, 70, 654-665.

Papi, M. (2010). The L2 motivational self system, L2 anxiety, and motivated behavior: A structural equation modelling approach. System, 38, 467-479.

Ryan, S. \& Dörnyei, Z. (2013). The long-term evolution of language motivation and the L2 self. Fremdsprachen in der Perspektive leben slangen Lernens, 89-100.

Sawir, E. (2005). Language difficulties of international students in Australia: The effects of prior learning experience. International Education Journal 6(5), 567-580.

Skehan, P. (1991). Individual differences in second language learning. Studies in Second Language Acquisition, 13(2), 275-298.

Şakiroğlu, B. \& Dikilitaş, K. (2012). Language learning motivation of Turkish tertiary level EFL students. Procedia - Social and Behavioral Sciences, 46, 3215-3219.

Taguchi, T., Magid, M. \& Papi, M. (2009). The L2 motivational self system amongst Chinese, Japanese and Iranian learners of English: A comparative study. In Zoltán Dörnyei \& Ema Ushioda (Eds.), Motivation, language identity and the L2 self (pp. 66-97). Bristol: Multilingual Matters.

Tyupa, S. (2011). A theoretical framework for back-translation as a quality assessment tool. New Voices in Translation Studies 7, 35-46.

Vaezi, Z. (2008). Language learning motivation among Iranian undergraduate students. World Applied Sciences Journal, 5(1), 54-61.

Walqui, A. (2000). Contextual factors in second language acquisition. ERIC Digest. https://files.eric.ed.gov/fulltext/ED444381.pdf (accessed 11 November 2019).

Williams, M. \& Burden, R. L. (1997). Psychology for language teachers. Cambridge: Cambridge University Press.

You, C., Dörnyei, Z. \& Csizér, K. (2016). Motivation, vision, and gender: A survey of learners of English in China. Language Learning, 66(1), 94-123. 
Table 1. Ideal L2 self of Turkish language learners.

\begin{tabular}{|c|c|c|c|c|c|c|c|c|c|c|}
\hline & \multicolumn{2}{|c|}{ 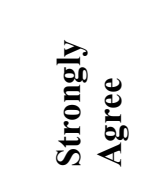 } & \multicolumn{2}{|r|}{$\underbrace{0}_{0}$} & \multicolumn{2}{|c|}{$\frac{\mathfrak{d}}{\stackrel{0}{C}}$} & \multicolumn{2}{|r|}{ 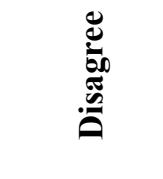 } & \multicolumn{2}{|c|}{ 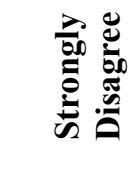 } \\
\hline & $\mathbf{f}$ & $\%$ & $\mathbf{f}$ & $\%$ & $\mathbf{f}$ & $\%$ & f & $\%$ & $\mathbf{f}$ & $\%$ \\
\hline $\begin{array}{l}\text { I can imagine myself having } \\
\text { discussions in English. }\end{array}$ & 34 & 28.8 & 48 & 40.7 & 24 & 20.3 & 12 & 10.2 & 0 & 0.0 \\
\hline I can imagine myself living abroad. & 72 & 61.0 & 41 & 34.7 & 3 & 2.5 & 2 & 1.7 & 0 & 0.0 \\
\hline $\begin{array}{l}\text { I can imagine myself as a fluent } \\
\text { speaker of English. }\end{array}$ & 40 & 34.2 & 55 & 47.0 & 19 & 16.2 & 3 & 2.6 & 0 & 0.0 \\
\hline $\begin{array}{l}\text { I can imagine myself writing letters/e- } \\
\text { mails in English accurately. }\end{array}$ & 41 & 35.0 & 61 & 52.1 & 9 & 7.7 & 6 & 5.1 & 0 & 0.0 \\
\hline $\begin{array}{l}\text { When I think about my future, I can } \\
\text { imagine myself using English in } \\
\text { different ways. }\end{array}$ & 38 & 32.5 & 62 & 53.0 & 16 & 13.7 & 1 & 0.9 & 0 & 0.0 \\
\hline $\begin{array}{l}\text { I can imagine myself speaking English } \\
\text { like a native speaker. }\end{array}$ & 30 & 25.4 & 46 & 39.0 & 31 & 26.3 & 9 & 7.6 & 2 & 1.7 \\
\hline $\begin{array}{l}\text { I can imagine myself using English } \\
\text { actively in my career in the future. }\end{array}$ & 66 & 56.4 & 39 & 33.3 & 11 & 9.4 & 0 & 0.0 & 1 & 0.9 \\
\hline $\begin{array}{l}\text { I can imagine myself speaking English } \\
\text { with people from different cultures for } \\
\text { both work and personal life. }\end{array}$ & 53 & 45.3 & 59 & 50.0 & 7 & 5.9 & 1 & 0.8 & 0 & 0.0 \\
\hline $\begin{array}{l}\text { I can imagine myself living abroad and } \\
\text { communicating with local people in } \\
\text { English. }\end{array}$ & 52 & 44.4 & 56 & 47.9 & 8 & 6.8 & 1 & 0.9 & 0 & 0.0 \\
\hline $\begin{array}{l}\text { I can imagine myself speaking English } \\
\text { with people of various nationalities. }\end{array}$ & 50 & 42.7 & 59 & 50.4 & 6 & 5.1 & 2 & 1.7 & 0 & 0.0 \\
\hline $\begin{array}{l}\text { I can imagine myself communicating } \\
\text { in English. }\end{array}$ & 53 & 45.3 & 58 & 49.6 & 4 & 3.4 & 1 & 0.9 & 1 & 0.9 \\
\hline $\begin{array}{l}\text { Things I would like to do in the future } \\
\text { require me to use English. }\end{array}$ & 84 & 71.2 & 25 & 21.2 & 8 & 6.8 & 0 & 0.0 & 1 & 0.8 \\
\hline $\begin{array}{l}\text { Learning English is important to me } \\
\text { because I can imagine myself } \\
\text { traveling to different countries. }\end{array}$ & 78 & 66.7 & 32 & 27.4 & 7 & 6.0 & 0 & 0.0 & 0 & 0.0 \\
\hline $\begin{array}{l}\text { I can imagine myself reading } \\
\text { magazines, newspapers, and books } \\
\text { published in English. }\end{array}$ & 54 & 46.2 & 45 & 38.5 & 13 & 11.1 & 3 & 2.6 & 2 & 1.7 \\
\hline $\begin{array}{l}\text { I can imagine myself watching movies } \\
\text { and TV series in English. }\end{array}$ & 80 & 68.4 & 34 & 29.1 & 3 & 2.6 & 0 & 0.0 & 0 & 0.0 \\
\hline $\begin{array}{l}\text { I can imagine myself as a part of the } \\
\text { undergraduate and postgraduate } \\
\text { programs in English. }\end{array}$ & 58 & 49.6 & 44 & 37.6 & 12 & 10.3 & 2 & 1.7 & 1 & 0.9 \\
\hline $\begin{array}{l}\text { I can imagine myself using English to } \\
\text { communicate with people from } \\
\text { different cultures. }\end{array}$ & 52 & 44.4 & 60 & 51.3 & 3 & 2.6 & 1 & 0.9 & 1 & 0.9 \\
\hline $\begin{array}{l}\text { I can imagine myself speaking English } \\
\text { in my social life. }\end{array}$ & 58 & 48.7 & 48 & 41.0 & 10 & 8.5 & 1 & 0.9 & 1 & 0.9 \\
\hline $\begin{array}{l}\text { I can imagine myself in the future } \\
\text { giving an English speech successfully } \\
\text { to the public in the future. }\end{array}$ & 39 & 33.3 & 48 & 41.0 & 25 & 21.4 & 4 & 3.4 & 1 & 0.9 \\
\hline
\end{tabular}


Table 2. Ought-to L2 self of Turkish language learners.

\begin{tabular}{|c|c|c|c|c|c|c|c|c|c|c|}
\hline & \multicolumn{2}{|c|}{ 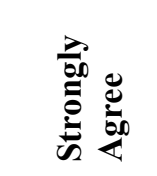 } & \multicolumn{2}{|c|}{ 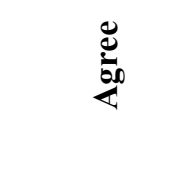 } & \multicolumn{2}{|c|}{ 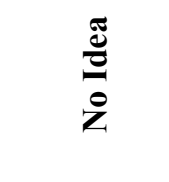 } & \multicolumn{2}{|c|}{ 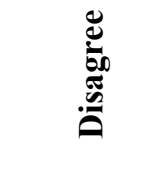 } & \multicolumn{2}{|c|}{ 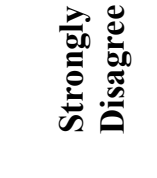 } \\
\hline & f & $\%$ & f & $\%$ & f & $\%$ & f & $\%$ & f & $\%$ \\
\hline $\begin{array}{l}\text { Learning English is important to me } \\
\text { because the people I care about think I } \\
\text { should learn this language. }\end{array}$ & 57 & 48.3 & 39 & 33.1 & 9 & 7.6 & 7 & 5.9 & 6 & 5.1 \\
\hline $\begin{array}{l}\text { Learning English is important to gain an } \\
\text { appreciation of family members. }\end{array}$ & 25 & 21.2 & 30 & 25.4 & 18 & 15.3 & 29 & 24.6 & 16 & 13.6 \\
\hline $\begin{array}{l}\text { Learning English is important to gain the } \\
\text { appreciation of the community to which } \\
\text { I belong. }\end{array}$ & 51 & 43.2 & 33 & 28.2 & 19 & 16.2 & 26 & 22.2 & 19 & 16.2 \\
\hline $\begin{array}{l}\text { Learning English is important to gain an } \\
\text { appreciation of my peers. }\end{array}$ & 25 & 21.6 & 22 & 19.0 & 21 & 18.1 & 31 & 26.7 & 17 & 14.7 \\
\hline $\begin{array}{l}\text { Learning English is important to gain an } \\
\text { appreciation of my teachers, especially in } \\
\text { education. }\end{array}$ & 39 & 33.3 & 29 & 24.8 & 16 & 13.7 & 19 & 16.2 & 14 & 12.0 \\
\hline $\begin{array}{l}\text { I have to learn English because I do not } \\
\text { want to fail in my English classes. }\end{array}$ & 51 & 43.2 & 38 & 32.2 & 11 & 9.3 & 12 & 10.2 & 6 & 5.1 \\
\hline $\begin{array}{l}\text { I have to learn English otherwise my } \\
\text { family will be disappointed. }\end{array}$ & 22 & 18.6 & 28 & 23.7 & 20 & 16.9 & 30 & 25.4 & 18 & 15.3 \\
\hline $\begin{array}{l}\text { I am learning English because my best } \\
\text { friends think it is important. }\end{array}$ & 15 & 12.9 & 17 & 14.7 & 19 & 16.4 & 37 & 31.9 & 28 & 24.1 \\
\hline $\begin{array}{l}\text { People around me believe I need to learn } \\
\text { English to be educated. }\end{array}$ & 26 & 22.2 & 55 & 47.0 & 16 & 13.7 & 13 & 11.1 & 7 & 6.0 \\
\hline $\begin{array}{l}\text { English is said to be one of the } \\
\text { prerequisites for communicating with } \\
\text { people from different cultures. }\end{array}$ & 68 & 57.6 & 41 & 34.7 & 8 & 6.8 & 0 & 0.0 & 1 & 0.8 \\
\hline $\begin{array}{l}\text { Studying abroad is said to be one of the } \\
\text { basic conditions of my career } \\
\text { advancement. }\end{array}$ & 65 & 55.6 & 43 & 36.8 & 6 & 5.1 & 1 & 0.9 & 2 & 1.7 \\
\hline $\begin{array}{l}\text { I must study English because it is } \\
\text { appreciated by the society to get high } \\
\text { marks from the standard English } \\
\text { examinations (TOEFL, Yök-Dil, YDS, } \\
\text { Exemption, etc.) applied in our country. }\end{array}$ & 35 & 29.7 & 32 & 27.1 & 22 & 18.6 & 15 & 12.7 & 14 & 11.9 \\
\hline
\end{tabular}


Table 3. Ideal L2 self category correlation with major Turkish language learners.

\begin{tabular}{|c|c|c|}
\hline $\begin{array}{l}\text { Independent } \\
\text { Variable }\end{array}$ & Dependent Variables & Sig. \\
\hline \multirow{19}{*}{ 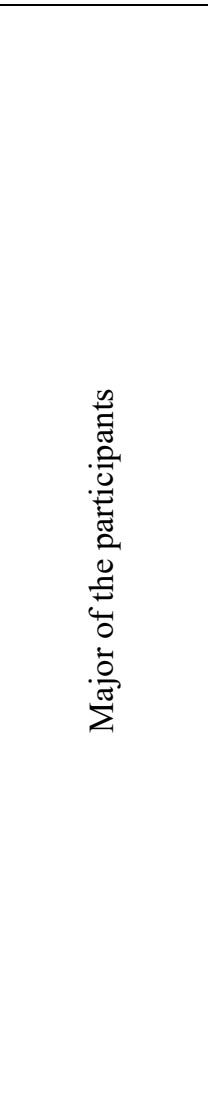 } & I can imagine myself having discussions in English. & ,898 \\
\hline & I can imagine myself living abroad. & 680 \\
\hline & I can imagine myself as a fluent speaker of English. & 643 \\
\hline & I can imagine myself writing letters/e-mails in English accurately. &, 542 \\
\hline & $\begin{array}{l}\text { When I think about my future, I can imagine myself using English in } \\
\text { different ways. }\end{array}$ & ,553 \\
\hline & I can imagine myself speaking English like a native speaker. & , 130 \\
\hline & I can imagine myself using English actively in my career in the future. & 204 \\
\hline & $\begin{array}{l}\text { I can imagine myself speaking English with people from different cultures } \\
\text { for both work and personal life. }\end{array}$ & ,583 \\
\hline & $\begin{array}{l}\text { I can imagine myself living abroad and communicating with local people in } \\
\text { English. }\end{array}$ & 072 \\
\hline & I can imagine myself speaking English with people of various nationalities. & ,379 \\
\hline & I can imagine myself communicating in English. &, 093 \\
\hline & Things I would like to do in the future require me to use English. &, 390 \\
\hline & $\begin{array}{l}\text { Learning English is important to me because I can imagine myself traveling } \\
\text { to different countries. }\end{array}$ & ,968 \\
\hline & $\begin{array}{l}\text { I can imagine myself reading magazines, newspapers, and books published } \\
\text { in English. }\end{array}$ & ,018* \\
\hline & I can imagine myself watching movies and TV series in English. & ,621 \\
\hline & $\begin{array}{l}\text { I can imagine myself as a part of the undergraduate and postgraduate } \\
\text { programs in English. }\end{array}$ &, 570 \\
\hline & $\begin{array}{l}\text { I can imagine myself using English to communicate with people from } \\
\text { different cultures. }\end{array}$ & ,287 \\
\hline & I can imagine myself speaking English in my social life. & ,979 \\
\hline & $\begin{array}{l}\text { I can imagine myself in the future giving an English speech successfully to } \\
\text { the public in the future. }\end{array}$ & ,188 \\
\hline
\end{tabular}

Table 4. Ought-toL2 self category correlation with major of Turkish language learners.

\begin{tabular}{|c|c|c|}
\hline $\begin{array}{l}\text { Independent } \\
\text { Variable }\end{array}$ & Dependent Variables & Sig. \\
\hline \multirow{12}{*}{ 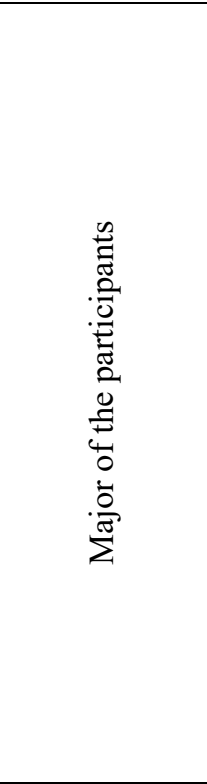 } & $\begin{array}{l}\text { Learning English is important to me because the people I care about think I } \\
\text { should learn this language. }\end{array}$ & ,064 \\
\hline & Learning English is important to gain an appreciation of family members. & ,971 \\
\hline & $\begin{array}{l}\text { Learning English is important to gain the appreciation of the community to } \\
\text { which I belong. }\end{array}$ & ,421 \\
\hline & Learning English is important to gain an appreciation of my peers. & ,868 \\
\hline & $\begin{array}{l}\text { Learning English is important to gain an appreciation of my teachers, } \\
\text { especially in education. }\end{array}$ & ,493 \\
\hline & I have to learn English because I do not want to fail in my English classes. & ,404 \\
\hline & I have to learn English otherwise my family will be disappointed. & 276 \\
\hline & I am learning English because my best friends think it is important. &, 184 \\
\hline & People around me believe I need to learn English to be educated. & 460 \\
\hline & $\begin{array}{l}\text { English is said to be one of the prerequisites for communicating with people } \\
\text { from different cultures. }\end{array}$ & 295 \\
\hline & $\begin{array}{l}\text { Studying abroad is said to be one of the basic conditions of my career } \\
\text { advancement. }\end{array}$ & ,708 \\
\hline & $\begin{array}{l}\text { I must study English because it is appreciated by the society to get high marks } \\
\text { from the standard English examinations (TOEFL, Yök-Dil, YDS, } \\
\text { Exemption, etc.) applied in our country. }\end{array}$ & ,505 \\
\hline
\end{tabular}




\begin{tabular}{|c|c|c|}
\hline Themes & $\begin{array}{rr}\text { Codes } \\
\end{array}$ & $\mathbf{f}$ \\
\hline \multirow{11}{*}{$\begin{array}{l}\text { Ideal L2 self-related } \\
\text { views to learn English, } \\
\text { the first set. }\end{array}$} & Communicating with foreign people & 8 \\
\hline & Reading in English & 3 \\
\hline & Getting self-confidence & 3 \\
\hline & Improving different perspectives & 2 \\
\hline & Getting new identities & 2 \\
\hline & Being a global citizen in the world & 2 \\
\hline & Having fun & 2 \\
\hline & Liking English & 2 \\
\hline & Importance of English & 1 \\
\hline & Traveling abroad & 1 \\
\hline & Learning a world language & 1 \\
\hline
\end{tabular}

Figure 1. Ideal L2 self-related views of Turkish language learners to learn English, the first set.

\begin{tabular}{cll}
\hline \multirow{2}{*}{ Themes } & \multicolumn{1}{c}{ Codes } & f \\
\hline & Communicating with foreign people & 4 \\
\cline { 2 - 3 } $\begin{array}{c}\text { Ideal L2 self-related } \\
\text { views to learn English } \\
\text { the second set }\end{array}$ & Learning a world language & 3 \\
\cline { 2 - 3 } & Liking English. & 1 \\
\cline { 2 - 3 } & Using it in one's daily life & 1 \\
\cline { 2 - 3 } & Having fun & 1 \\
\cline { 2 - 3 } & Traveling around the world & 1 \\
\cline { 2 - 3 } & Gaining new perspectives & 1 \\
\hline
\end{tabular}

Figure 2. Ideal L2 self-related views of Turkish language learners to learn English, the second set.

\begin{tabular}{cllc}
\hline Themes & Codes & f \\
Ought-to L2 self-related & For future department & For future job & 5 \\
views to learn English, the & For their personal lives & 5 \\
first set. & Reading academic papers & 5 \\
& For an international future & 2 \\
\hline
\end{tabular}

Figure 3. Ideal L2 self-related views of Turkish language learners to learn English, the first set.

\begin{tabular}{cllc}
\hline Themes & Codes & f \\
$\begin{array}{cll}\text { Ought-to L2 self-related } \\
\text { views to learn English, the }\end{array}$ & For their personal lives & & 6 \\
second set & For future job & & 4 \\
& For future department & & 1 \\
\hline & For examinations & 1 \\
\hline
\end{tabular}

Figure 4. Ought-to L2 self-related views of Turkish language learners to learn English, the second set. 